\title{
KECUKUPAN ZAT GIZI DAN PERUBAHAN STATUS GIZI PASIEN SELAMA DIRAWAT DI RUMAH SAKIT UMUM PUSAT SANGLAH DENPASAR
}

\author{
I Wayan Weta ${ }^{1}$ dan NL Partiwi Wirasamadi ${ }^{2}$ \\ ${ }^{1}$ Team Studi Gizi Klinik FK Unud/RSUP Sanglah \\ ${ }^{2}$ Instalasi Gizi RSUP Sanglah
}

\begin{abstract}
NUTRIENTS ADEQUACY AND CHANGES OF NUTRIRIONAL STATUS INDICES OF PATIENTS DURING HOSPITALIZED CARE IN CENTRAL GENERAL HOSPITAL OF SANGLAH DENPASAR
\end{abstract}

\begin{abstract}
Malnourished in hospitalized patients was reported relatively high (30-50\%). It was occurred during hospital care (iatrogenic malnutrition). It was potentially decrease the curing process, prolong length of stay, and rose up the cost of care. A prospective study was conducted in General Central Hospital of Sanglah Denpasar, included 42 male and female of hospitalized patients during period of February - Mart 2006 aged 18 to 70 years. The aim of the study was to assess the change of nutritional status index and nutrient adequacy of the subjects. The parameter of nutritional status (body weight and body mass index) in the first and last day of care, average of food and nutrient intake during hospitalized, estimate nutrient requirement and adequacy, was measured. The average length of stay was varied (6.5 \pm 5.25 days). The average macro nutrient intake of the subjects during hospitalized were less than the requirement level: energy $(78 \%)$, protein $(68 \%)$, carbohydrate $(78 \%)$, but not in fat $(99 \%)$. Macro nutrient adequacy in males were less than females subject. Indexes of nutritional status decreased; body weight (BW) $(P 0.016)$, body mass index (BMI) $(P 0.019)$. It was higher decreasing in males ( BW $P$ 0.029, BMI $P$ 0.027) than females (BW and BMI $P>0.05$ ). In conclusion, decreasing of nutritional status of patients was occurred in hospitalized patients. The adequacy of nutrient intake was lower than the requirement level. There are a complex nutritional problems in hospitalized patients. Nutritional service should be performed comprehensively in order to maintain nutritional status and increase curing process of the patients. It should be performed systematically and integrated through the team approach, which is play role in (1) define the diagnosis in term of clinical, biochemical, and nutritional status, (2) measure nutrient requirement and decide the feeding method, (3) carry out the nutritional support intervention, and (4) undertake the monitoring and evaluating as an impact of intervention.
\end{abstract}

Keywords: Hospitalized patients, Hospital of Sanglah, index of nutritional status, nutrient adequacy.

\section{PENDAHULUAN}

$\mathrm{K}$ ejadian kurang gizi merupakan salah satu permasalahan yang dihadapi rumah sakit dalam upaya penyembuhan pasien. Prevalensi kurang gizi di rumah sakit masih cukup tinggi $(30 \%$ $50 \%$ ). Sering sekali pasien menderita kurang gizi justru setelah dirawat dirumah sakit (iatrogenic malnutrition). Hasil penelitian yang dilakukan oleh Sunita Almatsier dibeberapa rumah sakit umum di Jakarta tahun 1991 menunjukkan 20 - 60 persen pasien menderita kurang gizi pada saat dirawat di rumah sakit'. Dian, dkk tahun 1999 melaporkan bahwa 0,9-5 persen pasien mengalami penurunan berat badan setelah 14 hari perawatan di bagian penyakit dalam RSUPN Ciptomangunkusumo Jakarta? Angka penurunan status gizi yang cukup tinggi juga didapatkan pada pengamatan pasien di rumah sakit pendidikan di Amerika, ditemukan 48 persen gizi kurang, 78 persen penurunan lingkar lengan atas (LLA), 70 persen kehilangan berat badan dan albumin menurun rata-rata $0,5 \mathrm{gr} / \mathrm{dl}$. Penelitian yang dilakukan di tiga rumah sakit yaitu RS Sanglah Denpasar, RS dr. Sardjito Yogyakarta dan RS Djamil Padang (Sarmila) oleh Kusumayanti, dkk tahun 2002 
ditemukan kejadian malnutrisi sebesar 57,14 persen dari RS DR. Sardjito , 18,57 persen berasal dari RS M Djamil Padang dan 24,29 persen berasal dari Rumah sakit Sanglah Denpasar. Rata-rata lama rawat inap pasien untuk RS Sanglah 5,15 hari, RS Dr. Sardjito 6,44 hari dan RS M Djamil 9 hari ${ }^{3}$. Penelitian Sarmila ini menyimpulkan bahwa pasien dengan asupan gizi yang adekuat mempunyai status gizi lebih baik pada saat keluar rumah sakit dibandingkan pasien yang asupannya tidak adekuat. Pasien dengan asupan energi yang tidak cukup mempunyai resiko 2,4 kali untuk terjadi malnutrisi. Asupan gizi di rumah sakit mempunyai hubungan erat dengan status gizi pasien selama perawatan, serta berpengaruh terhadap proses penyembu-han ${ }^{3}$.

Banyak faktor yang mempengaruhi masalah kurang gizi di rumah sakit diantaranya adalah: perkiraan kebutuhan gizi pasien yang tidak akurat, koordinasi yang kurang antar team kesehatan, seperti monitoring dan pencatatan berat badan dan tinggi badan yang tidak dilaksanakan, penggunaan parenteral nutrisi yang terlalu lama, asupan makanan yang kurang, sering memuasakan pasien untuk tujuan test diagnostik, terjadinya gangguan gastrointestinal (mual, tidak nafsu makan, kembung), tingkat beratnya penyakit dan status gizi awal masuk rumah sakit merupakan penyebab menurunnya keadaan gizi. Menurunnya keadaan gizi ini dapat dilihat dari penurunan berat badan. Pasienpasien yang rentan terhadap kejadian kurang gizi diantaranya adalah pasien yang berada pada ruang perawatan penyakit dalam, bedah, anak, geriatri, dan luka bakar.

Tingkat kecukupan zat gizi pada pasien yang dirawat inap di rumah sakit ditentukan oleh 2 faktor utama yaitu : asupan zat gizi dan utilisasi biologik zat gizi. Status gizi seseorang pada hakekatnya merupakan hasil keseimbangan antara konsumsi zat-zat gizi baik kualitas maupun kuantitasnya dan utilisasi biologik zat gizi tersebut. Status gizi akan menjadi optimal bila tubuh memperoleh cukup zat gizi dan digunakan secara efisien. Gangguan gizi dapat disebabkan oleh faktor yang bersifat primer maupun sekunder.
Faktor primer bisa berupa susunan makanan yang tidak sesuai dalam kualitas maupun kuantitasnya. Sedangkan faktor sekunder meliputi semua faktor yang menyebabkan zat-zat gizi tidak sampai di sel-sel tubuh setelah dikonsumsi, diantaranya adalah akibat adanya penyakitt,5. Asupan zat gizi yang adekuat bagi pasien yang dirawat inap di rumah sakit sangat diperlukan untuk membantu mempercepat proses penyembuhan pasien, memperpendek lama hari rawat, mencegah timbulnya komplikasi, menurunkan mortalitas dan morbiditas, yang pada akhirnya dapat menghemat biaya pengobatan.

Di Rumah Sakit Umum Pusat Sanglah Denpasar, penilaian status gizi pasien rawat inap tidak dilakukan secara rutin, penilaian status gizi secara khusus hanya dilakukan untuk kasus-kasus tertentu saja. Penentuan kebutuhan zat gizi masih dilakukan secara konvensional (umum), tidak dihitung perindividu (per kasus). Adapun tujuan dari penelitian ini adalah untuk mengetahui tingkat kecukupan konsumsi zat gizi pasien selama dirawat dan mengetahui perubahan indeks status gizi (berat badan dan IMT) pasien selama perawatan.

\section{BAHAN DAN CARA}

\section{Desain, Tempat dan Waktu}

Penelitian dilakukan di Rumah Sakit Umum Pusat Sanglah Denpasar di bangsal Teratai (kelas II) dan Widuri (kelas III), mulai tanggal 1 Pebruari sampai dengan tanggal 13 Maret 2006, dengan menggunakan desain kohort prospektif. Populasi dari penelitian adalah seluruh pasien dewasa wanita dan pria yang dirawat inap di bangsal Teratai dan Widuri RSUP Sanglah Denpasar dengan kriteria inklusi: usia pasien $\geq 18$ tahun, dalam keadaan sadar dan kooperatif, bersedia ikut dalam penelitian, dapat diukur tinggi dan berat badan saat awal dan akhir perawatan. Adapun kriteria eksklusi: adanya edema dan asites, pasien dengan nutrisi parenteral total, adanya gangguan saluran cerna. 


\section{Sampel Penelitian}

Colton ${ }^{6}$ :

Besar sampel ditentukan dengan rumus

Besar deviasi $(\mathrm{d})=\mathrm{P} 1-\mathrm{P} 0=0,24-0,08=$ 0,16 . Tingkat kemaknaan sebesar $Z \alpha=$ 1,96 dengan $\alpha=5 \%$ dan $Z \beta=0,84$ dengan $\beta=20 \%$. Berdasarkan rumus di atas diperoleh sampel sebesar 42 orang. Pengambilan sampel dilakukan dengan cara concecutive sampling yaitu setiap pasien yang memenuhi kriteria akan dipilih sebagai sampel, sampai jumlah sampel memenuhi.

\section{Cara Pengumpulan Data}

Data identitas sampel dikumpulkan dengan menggunakan quesioner yang meliputi: umur, jenis kelamin, diagnosis penyakit, bangsal dan kelas perawatan, bentuk makanan yang diberikan, tanggal masuk dan tanggal keluar rumah sakit. Berat badan (BB) diukur dua kali, yaitu pada awal masuk (hari pertama) dan hari terakhir perawatan. Berat badan diukur dengan timbangan elektronik Seca dengan ketelitian $0,1 \mathrm{~kg}$. Pasien ditimbang pada posisi berdiri dengan pakaian minimal, pembacaan dilakukan dua kali, kemudian diambil nilain rata-rata. Tinggi badan (TB) diukur satu kali pada saat masuk RS (hari pertama), dengan mikrotois ketelitian $0,1 \mathrm{~cm}$, tanpa alas kaki, dalam posisi tegak. Indeks mass tubuh (IMT) dihitung dua kali (awal dan akhir) dengan rumus:

$$
\text { IMT }=\frac{B B(k g)}{T B^{2}(m)}
$$

Status gizi kurang bila IMT $<18,5$ dan status gizi baik bila IMT $\geq 18,5$. Kebutuhan energi basal ditentukan dengan menggunakan formula resting energy expenditure (REE) dari Harris Benedict, berdasarkan umur (U, tahun), jenis kelamin, tinggi badan $(\mathrm{TB}, \mathrm{cm})$ dan berat badan $(\mathrm{BB}$, $\mathrm{kg}$ ) sebagai berikut:

REE laki-laki $=66,5+13,7 \mathrm{BB}+5,0 \mathrm{~TB}-6,8 \mathrm{U}$ REE perempuan $=665+9,7 \mathrm{BB}+1,7 \mathrm{~TB}-4,7 \mathrm{U}$.

Kebutuhan energi total diperhitungkan dari REE, efek termik makanan, faktor stres dan aktivitas fisik setiap individu. Sedangkan kebutuhan protein, karbohidrat dan lemak disesuaikan dengan berat badan dan jenis penyakitn $7,8,9,10,11,12$. Asupan energi, protein, karbohidrat dan lemak harian selama dirawat diperhitungkan dari makanan yang dikonsumsi baik yang berasal dari rumah sakit maupun luar rumah sakit. Asupan makanan rumah sakit diperoleh dengan cara mengamati sisa makanan dengan metode visual comstock, sedangkan asupan dari luar rumah sakit dengan metode estimated food records. kemudian dikonversikan ke dalam energi, protein, lemak, dan karbohidrat dengan menggunakan program Food Processor 2 (FP2).

Data tingkat konsumsi diperoleh dengan cara membandingkan rata-rata asupan zat gizi dengan kebutuhan zat gizi pasien. Tingkat konsumsi dihitung dari rata-rata asupan energi, protein, lemak dan karbohidrat selama dirawat baik yang berasal dari rumah sakit maupun luar rumah sakit dibandingkan dengan kebutuhan pasien. Asupan zat gizi dikategorikan cukup apabila $\geq 80 \%$ dari kebutuhan, sedangkan tidak cukup apabila $<80 \%$ dari kebutuhan $9,10,11,13$

\section{Alat Pengumpul Data}

Pencatatan konsumsi makanan digunakan kuesioner. Timbangan berat badan elektrik merk Seca buatan Jerman dengan ketelitian $0,1 \mathrm{~kg}$. Microtoice yang memiliki ketelitian $0,1 \mathrm{~cm}$ digunakan untuk mengukur tinggi badan

\section{Pengolahan dan Analisis Data}

Analisis data dilakukan dengan perangkat komputer secara deskriptif dan analitik sesuai dengan tujuan penelitian dan jenis data.

\section{HASIL}

\section{Karakteristik Sampel}

Sampel penelitian sebenyak 42 orang masing-masing terdiri dari 21 orang laki-laki (50\%) dan 21 orang perempuan $(50 \%)$. Kisaran umur subjek antara 18 sampai 70 tahun. Berdasarkan bangsal dan kelas perawatan sebanyak 33 orang $(78,6 \%)$ 
dirawat di Bangsal Kelas II dan 9 orang $(21,4 \%)$ dirawat di Bangsal Kelas III. Ratarata lama hari rawat sampel yang diamati adalah 6,4 $\pm 5,25$ hari. Berdasarkan jenis diet yang diberikan (tabel 1) sebagian besar adalah makanan biasa sebanyak 19 sampel $(45,2 \%)$, makanan lunak sebanyak 14 sampel $(33,4 \%)$

Tabel 1

Sebaran Sampel berdasarkan Jenis Diit yang Diberikan

\begin{tabular}{lcc}
\hline Jenis Diet & $\mathrm{n}$ & $\%$ \\
\hline Biasa (Nasi) & 19 & 45,2 \\
Lunak & 14 & 33,4 \\
Diabetes Melitus (B1 1900) & 2 & 4,7 \\
Diit Jantung & 3 & 7,2 \\
Rendah Protein 40 gram & 4 & 9,5 \\
\hline
\end{tabular}

Jenis penyakit yang diderita sampel cukup bervariasi, namun penyakit yang terbanyak adalah demam berdarah yaitu

sebesar 28 orang $(66,7 \%)$ seperti terlihat pada Tabel 2.

Tabel 2

Sebaran Sampel berdasarkan Jenis Penyakit

\begin{tabular}{lcc}
\hline Jenis Penyakit & $\mathrm{n}$ & $\%$ \\
\hline Penyakit Ginjal Kronik & 4 & 9,6 \\
Penyakit Demam Berdarah & 28 & 66,7 \\
Kencing Manis (diabetes melitus) & 2 & 4,7 \\
Hipertensi & 1 & 2,4 \\
Penyakit Jantung Koroner & 2 & 4,7 \\
Penyakit Paru Obstruksi Kronis & 2 & 4,7 \\
Penyakit Lainnya & 3 & 7,2 \\
\hline Total & 42 & 100,0 \\
\hline
\end{tabular}

\section{Tingkat Kecukupan Zat Gizi}

\section{Kebutuhan Gizi}

Kebutuhan zat gizi sampel diperhitungkan berdasar metabolisme basal (BMR), aktivitas fisik dan faktor stress. Perhitungan BMR dilakukan dengan menggunakan formula resting energy expenditure (REE) Harris Benedict. Sedangkan kebutuhan protein, karbohidrat dan lemak disesuaikan dengan berat badan dan jenis penyakitnya (Tabel 3).

Tabel 3

Rata- Rata Kebutuhan Zat Gizi Sampel berdasarkan Jenis Kelamin

\begin{tabular}{lcc}
\hline & \multicolumn{2}{c}{ Kebutuhan Zat gizi } \\
\cline { 2 - 3 } Zat Gizi & Laki-laki & Perempuan \\
& (rata-rata $\pm S D)$ & $2012,89 \pm 208,64$ \\
\hline Energi (kkal) & $2381,31 \pm 251,16$ & $73,35 \pm 19,01$ \\
Protein (g) & $86,29 \pm 26,69$ & $329,25 \pm 34,83$ \\
Karbohidrat (g) & $389,97 \pm 34,92$ & $44,72 \pm 4,63$ \\
Lemak (g) & $52,89 \pm 5,59$ & \\
\hline
\end{tabular}




\section{Asupan Zat Gizi}

Asupan energi, protein, lemak dan karbohidrat pada sampel penelitian diukur menggunakan metode visual comstock dengan cara menghitung sisa makanan selama dirawat di rumah sakit. Sedangkan
Makanan dari luar rumah sakit dihitung dengan menggunakan metode estimated food record. Rata-rata asupan zat gizi pasien selama dirawat di rumah sakit dapat dilihat pada Tabel 4.

Tabel 4

Rata-rata Asupan Zat gizi Sampel Menurut Jenis Kelamin

\begin{tabular}{lcc}
\hline & \multicolumn{2}{c}{ Asupan Zat gizi } \\
\cline { 2 - 3 } Zat Gizi & Laki-laki & Perempuan \\
& $($ mean $\pm S D)$ & $($ mean $\pm S D)$ \\
\hline Energi (kkal) & $1726,45 \pm 547,02$ & $1678,23 \pm 390,61$ \\
Protein (g) & $49,57 \pm 20,05$ & $50,58 \pm 15,43$ \\
Karbohidrat (g) & $284,36 \pm 81,32$ & $274,66 \pm 64,42$ \\
Lemak (g) & $48,48 \pm 21,68$ & $47,34 \pm 15,39$ \\
\hline
\end{tabular}

\section{Kecukupan Gizi}

Tingkat kecukupan gizi dihitung dengan membandingkan asupan zat gizi masingmasing pasien baik yang berasal dari rumah sakit maupun luar rumah sakit dengan kebutuhannya (Table 5). Tingkat konsumsi sampel secara umum berada di bawah kebutuhan (energi sebesar 78,14\%; protein $68,35 \%$; karbohidrat $78,35 \%$; dan lemak $99,29 \%)$.

Tabel 5

Rata-rata tingkat konsumsi terhadap kebutuhan subjek selama perawatan

\begin{tabular}{lccc}
\hline \multirow{2}{*}{ Zat Gizi* $^{*}$} & \multicolumn{3}{c}{ Persentase Konsumsi Zat Gizi } \\
\cline { 2 - 4 } & $\begin{array}{c}\text { Dari RS } \\
\text { (mean } \pm \text { SD) }\end{array}$ & $\begin{array}{c}\text { Dari Luar RS } \\
\text { (mean } \pm S D)\end{array}$ & $\begin{array}{c}\text { Total } \\
\text { (mean } \pm S D)\end{array}$ \\
\hline Energi (\%) & $56,18 \pm 16,68$ & $22,01 \pm 18,80$ & $78,14 \pm 21,30$ \\
Protein (\%) & $54,54 \pm 22,62$ & $13,81 \pm 21,07$ & $68,35 \pm 33,19$ \\
Karbohidrat (\%) & $53,69 \pm 15,18$ & $24,66 \pm 17,03$ & $78,35 \pm 19,76$ \\
Lemak (\%) & $78,00 \pm 28,89$ & $21,29 \pm 34,44$ & $99,29 \pm 38,96$ \\
\hline
\end{tabular}

* \% terhadap kebutuhan

Tabel 6

Rata-rata tingkat konsumsi terhadap kebutuhan pada sampel laki-laki

\begin{tabular}{lccc}
\hline & \multicolumn{3}{c}{ Persen Konsumsi Zat Gizi } \\
\cline { 2 - 4 } Zat Gizi ${ }^{*}$ & $\begin{array}{c}\text { Dari RS } \\
(\text { mean } \pm S D)\end{array}$ & $\begin{array}{c}\text { Dari Luar RS } \\
(\text { mean } \pm S D)\end{array}$ & $\begin{array}{c}\text { Total } \\
(\text { mean } \pm S D)\end{array}$ \\
\hline Energi (\%) & $52,45 \pm 17,62$ & $20,04 \pm 19,20$ & $72,5 \pm 22,09$ \\
Protein (\%) & $50,68 \pm 22,96$ & $12,47 \pm 22,02$ & $63,15 \pm 33,65$ \\
Karbohidrat (\%) & $50,24 \pm 14,41$ & $22,62 \pm 17,45$ & $72,86 \pm 19,46$ \\
Lemak (\%) & $73,04 \pm 33,32$ & $19,49 \pm 36,88$ & $92,52 \pm 43,16$ \\
\hline
\end{tabular}

* \% terhadap kebutuhan 
Persentase asupan makanan dari rumah sakit lebih tinggi dari pada asupan makanan dari luar rumah sakit. Tingkat konsumsi sampel berdasarkan jenis kelamin tertera pada Tabel 6 dan Tabel 7. Rata-rata konsumsi pasien laki-laki untuk energi, protein dan lemak berada dibawah kebutuhan. Persentase asupan makanan dari rumah sakit lebih tinggi dari pada luar rumah sakit untuk semua zat gizi. Tingkat konsumsi energi pada sampel perempuan sebesar 83,79 persen; protein 73,55 persen; karbohidrat 83,83 persen. Bahkan konsumsi lemak sudah memenuhi kebutuhan $(106,06 \%)$.

Tabel 7

Rata-rata tingkat konsumsi terhadap kebutuhan pada sampel perempuan

\begin{tabular}{lccc}
\hline & \multicolumn{3}{c}{ Persen Konsumsi Zat Gizi } \\
\cline { 2 - 4 } Zat Gizi & $\begin{array}{c}\text { Dari RS } \\
(\text { mean } \pm S D)\end{array}$ & $\begin{array}{c}\text { Dari Luar RS } \\
(\text { mean } \pm S D)\end{array}$ & $\begin{array}{c}\text { Total } \\
(\text { mean } \pm S D)\end{array}$ \\
\hline Energi (\%) & $59,82 \pm 15,21$ & $23,97 \pm 18,64$ & $83,79 \pm 19,38$ \\
Protein (\%) & $58,40 \pm 22,14$ & $15,15 \pm 20,53$ & $73,55 \pm 32,70$ \\
Karbohidrat (\%) & $57,14 \pm 15,48$ & $26,69 \pm 16,77$ & $83,83 \pm 18,93$ \\
Lemak (\%) & $82,97 \pm 23,43$ & $23,09 \pm 32,63$ & $106,06 \pm 33,94$ \\
\hline
\end{tabular}

* \% terhadap kebutuhan

Tabel 8

Status tingkat kecukupan energi berdasarkan jenis kelamin, umur, kelas perawatan, lama hari rawat, dan bentuk makanan

\begin{tabular}{llcccc}
\hline & & \multicolumn{4}{c}{ Konsumsi Energi } \\
\cline { 3 - 6 } \multicolumn{1}{c}{ Variabel } & \multicolumn{3}{c}{ Cukup } & \multicolumn{2}{c}{ Tidak Cukup } \\
\cline { 3 - 6 } & & $\mathrm{n}$ & $\%$ & $\mathrm{n}$ & $\%$ \\
\hline \multirow{2}{*}{ Jenis Kelamin } & Laki-laki & 9 & 42,8 & 12 & 57,2 \\
& Perempuan & 12 & 57,2 & 9 & 42,8 \\
\hline Kelompok Umur & $16-18$ & 1 & 100,0 & - & - \\
(tahun) & $19-29$ & 6 & 100,0 & 8 & 57,2 \\
& $30-49$ & 11 & 57,9 & 8 & 42,1 \\
& $50-64$ & 3 & 42,8 & 4 & 57,2 \\
& $>65$ & - & - & 1 & 100,0 \\
\hline Kelas Perawatan & II & 15 & 45,5 & 18 & 54,5 \\
& III & 6 & 66,7 & 3 & 33,3 \\
\hline Lama Hari Rawat & $1-3$ hari & 5 & 71,4 & 2 & 28,6 \\
& $4-6$ hari & 12 & 50,0 & 12 & 50,0 \\
& $7-9$ hari & 3 & 50,0 & 3 & 50,0 \\
& $>10$ hari & 1 & 25,0 & 4 & 75,0 \\
\hline \multirow{2}{*}{ Bentuk Makanan } & Biasa & 8 & 42,1 & 11 & 57,9 \\
& Khusus & 13 & 56,5 & 10 & 43,5 \\
\cline { 2 - 6 } & & & & &
\end{tabular}

Asupan masing-masing zat gizi sample dibandingkan dengan kebutuhan dikategorikan dalam asupan cukup bila mengonsumsi 80 persen kebutuhan dan dikatakan asupan tidak cukup bila mengonsumsi kurang dari 80 persen kebutuhan. Dari tabel diatas dapat dilihat bahwa secara umum asupan sampel masih kurang, kecuali lemak yang sudah 
mencapai katagori cukup. Bila dilihat berdasarkan jenis kelamin untuk pasien lakilaki hampir semua tingkat konsumsi berada dibawah kebutuhan kecuali lemak yang sudah cukup. Sedangkan pada pasien perempuan asupan zat gizi sudah mencapai kategori cukup kecuali untuk asupan protein yang masih berada di bawah kebutuhan (Tabel 8 dan Tabel 9).

Tabel 9

Status tingkat kecukupan protein berdasarkan jenis kelamin, umur, kelas perawatan, lama hari rawat, dan bentuk makanan

\begin{tabular}{|c|c|c|c|c|c|}
\hline \multirow{3}{*}{ Variabel } & & \multicolumn{4}{|c|}{ Konsumsi Protein } \\
\hline & & \multicolumn{2}{|c|}{ Cukup } & \multicolumn{2}{|c|}{ Tidak Cukup } \\
\hline & & $\mathrm{n}$ & $\%$ & $\mathrm{n}$ & $\%$ \\
\hline \multirow[t]{2}{*}{ Jenis Kelamin } & Laki-laki & 4 & 19,0 & 17 & 81 \\
\hline & Perempuan & 6 & 28,5 & 15 & 71,5 \\
\hline \multirow{5}{*}{$\begin{array}{l}\text { Kelompok umur } \\
\text { (tahun) }\end{array}$} & $16-18$ & 1 & 100,0 & - & - \\
\hline & $19-29$ & 2 & 14,3 & 12 & 85,7 \\
\hline & $30-49$ & 3 & 15,8 & 16 & 84,2 \\
\hline & $50-64$ & 4 & 57,1 & 3 & 42,9 \\
\hline & $>65$ & - & - & 1 & 100,0 \\
\hline \multirow{2}{*}{ Kelas Perawatan } & $\|$ & 9 & 27,3 & 24 & 72,7 \\
\hline & III & 1 & 11,1 & 8 & 88,9 \\
\hline \multirow[t]{4}{*}{ Lama Hari Rawat } & 1-3 hari & 1 & 14,3 & 6 & 85,7 \\
\hline & 4-6 hari & 4 & 16,7 & 20 & 83,3 \\
\hline & 7-9 hari & 3 & 50,0 & 3 & 50,0 \\
\hline & $>10$ hari & 2 & 40,0 & 3 & 60,0 \\
\hline \multirow[t]{2}{*}{ Bentuk Makanan } & Biasa & 2 & 10,5 & 17 & 89,5 \\
\hline & Khusus & 8 & 34,8 & 15 & 65,2 \\
\hline
\end{tabular}

Tabel 10

Perubahan Berat Badan Sampel menurut Lama Hari Rawat

\begin{tabular}{|c|c|c|c|c|c|}
\hline \multirow{2}{*}{ Lama Hari Rawat } & \multirow{2}{*}{$\mathrm{n}$} & \multicolumn{2}{|c|}{ Berat Badan (kg) } & \multirow{2}{*}{$\begin{array}{c}\text { Beda } \\
\text { Mean } \\
(\mathrm{kg})\end{array}$} & \multirow{2}{*}{$p^{*}$} \\
\hline & & $\begin{array}{l}\text { Awal } \\
(\text { Mean } \pm S D)\end{array}$ & $\begin{array}{l}\text { Akhir } \\
(\text { Mean } \pm S D)\end{array}$ & & \\
\hline 1-3 hari & 7 & $51,29 \pm 5,71$ & $51,0 \pm 5,92$ & 0,29 & 0,126 \\
\hline 4-6 hari & 24 & $58,96 \pm 15,82$ & $58.82 \pm 15,64$ & 0,14 & 0,316 \\
\hline 7-9 hari & 6 & $63,1 \pm 7,67$ & $62,67 \pm 7,3$ & 0,43 & 0,295 \\
\hline$>10$ hari & 5 & $56,18 \pm 11,83$ & $55,14 \pm 11,6$ & 1,04 & 0,175 \\
\hline Total & 42 & $57,94 \pm 13,36$ & $57,63 \pm 13,22$ & 0,31 & 0,016 \\
\hline
\end{tabular}

${ }^{*} p$ : uji statistik dengan t-tes berpasangan

\section{Indeks Status Gizi}

\section{Berat Badan Pasien}

Rata-rata berat badan awal subjek adalah: $57,94 \quad( \pm 13,36) \mathrm{kg}$. Sedangkan berdasarkan pengamatan pada saat pasien keluar dari rumah sakit diperoleh nilai ratarata berat badan $57,63( \pm 13,22) \mathrm{kg}$. Dari pengamatan nilai rata-rata ini secara umum terjadi penurunan yang bermakna rata-rata berat badan sebesar $0,31 \mathrm{~kg}(P=0,016)$. 
Akan tetapi bila dilihat menurut lama perawatan tidak didapat perbedaan bermakna (Tabel 10).

Perubahan berat badan berdasarkan jenis kelamin dapat dilihat pada Tabel 11, pada sampel laki-laki terdapat penurunan berat badan selama perawatan terjadi penurunan yang bermakna $(P=0,029)$. Sedangkan pada kelompok perempuan walaupun terdapat penurunan berat badan namun penurunan ini tidak bermakna secara statistik.

Tabel 11

Perubahan Berat Badan Sampel menurut Jenis Kelamin

\begin{tabular}{lccc}
\hline \multirow{2}{*}{ Jenis Kelamin } & \multicolumn{2}{c}{ Berat Badan $(\mathrm{kg})$} & \multirow{2}{*}{$p^{*}$} \\
\cline { 2 - 3 } & $\begin{array}{c}\text { Awal } \\
(\text { Mean } \pm S D)\end{array}$ & $\begin{array}{c}\text { Akhir } \\
(\text { Mean } \pm S D)\end{array}$ & \\
\hline Laki - laki (21) & $65,11 \pm 11,82$ & $64,65 \pm 11,75$ & 0,029 \\
Perempuan (21) & $50,77 \pm 10,87$ & $50,60 \pm 10,79$ & 0,289 \\
\hline Total (42) & $57,94 \pm 13,36$ & $57,63 \pm 13,22$ & 0,016 \\
\hline
\end{tabular}

*diuji dengan t-tes berpasangan.

\section{Indeks Massa Tubuh (IMT)}

Rata-rata IMT sampel awal masuk rumah sakit adalah $21,8( \pm 3,94) \mathrm{kg} / \mathrm{m}^{2}$, dan menurun bermakna menjadi $21,68( \pm 3,92) \mathrm{kg} / \mathrm{m}^{2}$ pada saat keluar rumah sakit $(P=0,019)$. Tetapi bila dilihat per lama perawatan tidak terlihat penurunan IMT yang signifikan meskipun secara klinis terjadi penurunan IMT.

Tabel 12

Perubahan IMT sampel menurut lama hari rawat

\begin{tabular}{lccccc}
\hline Lama Hari Rawat & $\mathrm{n}$ & \multicolumn{2}{c}{ Indek Masa Tubuh $\left(\mathrm{kg} / \mathrm{m}^{2}\right)$} & \multirow{2}{*}{$\begin{array}{c}\text { Beda } \\
\text { mean }\left(\mathrm{kg} / \mathrm{m}^{2}\right)\end{array}$} & $p^{*}$ \\
\cline { 3 - 4 } & 7 & $\begin{array}{c}\text { Awal } \\
(\text { mean } \pm S D)\end{array}$ & $\begin{array}{c}\text { Akhir } \\
(\text { mean } \pm S D)\end{array}$ & & \\
\hline 1-3 hari & 24 & $22,08 \pm 2,15$ & $19,97 \pm 2,26$ & 0,11 & 0,120 \\
4-6 hari & 6 & $23,64 \pm 3,05$ & $22,0 \pm 4,54$ & 0,07 & 0,332 \\
$7-9$ hari & 5 & $20,68 \pm 3,25$ & $23,5 \pm 2,36$ & 0,14 & 0,341 \\
$>10$ hari & 42 & $21,8 \pm 3,94$ & $21,68 \pm 3,92$ & 0,12 & 0,019 \\
\hline Total & 24,33 & 0,37 & 0.172 \\
\hline
\end{tabular}

*: uji statistik dengan t-tes berpasangan

Perubahan IMT sampel selama perawatan berdasarkan jenis kelamin, terdapat penurunan bermakna pada sampel laki-laki $\quad(P=0,027), \quad$ sedangkan pada perempuan tidak terjadi penurnan bermakna $(P=0,296)$ (Tabel 13). 
Tabel 13

Perubahan IMT Sampel menurut Jenis Kelamin

\begin{tabular}{lccc}
\hline \multirow{2}{*}{ Jenis Kelamin } & \multicolumn{2}{c}{$\mathrm{BMI}\left(\mathrm{Kg} / \mathrm{m}^{2}\right.$} & $p^{*}$ \\
\cline { 2 - 3 } & $\begin{array}{c}\text { Awal } \\
(\text { mean } \pm S D)\end{array}$ & $\begin{array}{c}\text { Akhir } \\
(\text { mean } \pm S D)\end{array}$ & \\
\hline Laki - laki (21) & $23,13 \pm 3,89$ & $22,97 \pm 3,9$ & 0,027 \\
Perempuan (21) & $20,46 \pm 3,60$ & $20,39 \pm 3,57$ & 0,296 \\
\hline Total (42) & $21,8 \pm 3,94$ & $21,68 \pm 3,92$ & 0,019 \\
\hline$p^{*} .0,05$ diuji dengan $t$ - tes berpasangan. & &
\end{tabular}

\section{PEMBAHASAN}

Menurunnya indeks status gizi (BB dan IMT) selama perawatan rumah sakit pada penelitian ini, sejalan dengan tidak terpenuhinya kebutuhan zat gizi pasien yang dirawat. Menurut hasil-hasil penelitian sebelumnya, hal ini nampaknya terjadi secara umum pada pasien yang dirawat dirumah sakit, yang dikenal sebagai malnutrisi iatrogenik ${ }^{14,15}$. Malnutrisi iatrogenik ini terjadi akibat tidak terpenuhinya kebutuhan gizi yang disebabkan oleh berbagai hal, baik faktor internal maupun eksternal.

Faktor internal dapat berupa penurunan kondisi fisik pasien, gangguan fisiologis dan utilitas sistem pencernaan, dan kondisi penyakit pasien sangat berpengaruh terhadap kemampuan penerimaan diet. Faktor eksternal tidak kalah pentingnya sebagai faktor penentu asupan gizi, seperti lingkungan, sikap dan perilaku pemberi pelayanan dan menu yang disajikan. Perlakuan dan tindakan manipulatif dalam prosedur perawatan pasien seperti memuasakan pasien dalam rangka prosedur diagnostik medik, dan terapi tindakan medik juga sering dilaporkan sebagai kontributor penurunan status gizi. Untuk memenuhi tingkat kecukupan gizi pasien yang dirawat dirumah sakit semua faktor di atas harus menjadi perhatian dari team kesehatan di rumah sakit. Harus ada team khusus (gizi klinik) yang bertanggungjawab dalam rangka memberikan pelayanan dan tunjangan gizi yang profesional ${ }^{16}$.
Pelayanan gizi tidak bisa dilakukan menggunakan pendekatan kelompok pasien, akan tetapi hendaknya dilakukan secara individual kasus per kasus, berorientasi pada kebutuhan zat gizi dan kodisi kesehatan setiap pasien. Penerapannya dilakukan secara sitematis dan terstruktur, melalui beberapa tahapan yaitu berturut-turut; identifikasi dan diagnosis masalah gizi, asessemen kebutuhan zat gizi, penyusunan menu, evaluasi asupan dan tingkat kecukupan gizi dan monitoring perkembangan status gizi dan penyakit dasarnya. Pelayanan gizi yang profesional melalui Team khusus (gizi klinik) seyogyanya menjadi bagian integral dari pelayanan rumah sakit secara keseluruhan. Integrasi dari berbagai disiplin menjadi satu team dalam pelayanan rumah sakit akan meningkatkan efektifitas pelayanan, yang pada gilirannya akan meningkatkan angka kesembuhan, dan memperpendek lama perawatan (LOS).

Meningkatnya angka kesembuhan dan memendeknya LOS adalah cermin dari peningkatan kualitas jasa pelayanan kesehatan. Dengan memendeknya LOS berarti pula dapat memperkecil aspek pembiayaan perawatan. Dengan demikian dapat dikatakan bahwa dengan memberikan pelayanan gizi profesional, sistematik dan berorientasi pada kasus, merupakan salah satu sisi pelayanan yang menghasilkan produk yang cost-effectiveness. Produk pelayanan yang cost-effectiveness dipandang yang paling menguntungkan dari semua pihak (pasien, pemberi pelayanan, 
dan/atau pengelaloa dana; asuransi kesehatan, pemerintah dan sebagainya), ditengah kompleksitas pelayanan kedokteran dewasa ini.

\section{SIMPULAN DAN SARAN}

\section{Simpulan}

Berdasarkan hasil penelitian ini, maka dapat diambil kesimpulan sebagai berikut:

1. Rata-rata asupan zat gizi subjek berada di bawah kebutuhan $(78,14 \%$ energi; $68,35 \%$ protein; $78,35 \%$ karbohidrat), kecuali lemak $(99,29 \%)$. Bila dilihat berdasarkan jenis kelamin, rata-rata tingkat konsumsi pada sampel laki-laki lebih rendah dari pada sampel perempuan.

2. Secara umum (tanpa memandang jenis kelamin) terjadi penurunan rata-rata berat badan $(p=0,016)$, dan IMT subjek $(p=0,019)$ selama perawatan. Bila dilihat berdasarkan jenis kelamin, penurunan indeks status gizi pada laki-laki lebih besar dari pada perempuan berat (BB: $p=0,029$ vs 0,289 , IMT: $p=0,027$ vs $0,296)$.

\section{Saran}

Berdasarkan kenyataan di atas perlu dikembangkan upaya pelayanan gizi rumah sakit yang lebih sistematis, menyeluruh (comprehensive) dan terpadu (integrated) dengan pendekatan team, sebagai bagian integral dari upaya pelayanan rumah sakit secara keseluruhan. Pelayanan diet hendaknya dilakukan mengacu pada kebutuhan zat gizi pasien, sesuai dengan status gizi, metabolik dan kondisi penyakit. Perlu dikembangkan standar operasional prosedur untuk pelayanan gizi mulai dari penetapan status gizi, diagnosa penyakit, perhitungan kebutuhan zat gizit, penyusunan menu, penyajian, monitoring dan evaluasi dari pelayanan gizi itu sendiri. Untuk melaksanakan itu semua perlu dikembangan team kesehatan terpadu yang melibatkan para profesional dari berbagai disiplin ilmu (ahli gizi, ahli diet, dokter spesialis, perawat, analis dan sebagainya).

\section{RUJUKAN}

1. Almatsier S, Jusat I, Akmal N. Persepsi Pasien Terhadap Makanan di Rumah Sakit. Gizi Indonesia, 1992, 17(1-2): 8796.

2. Dian PP, Nita I, dan Oktorudin $\mathrm{H}$. Faktor - Faktor Yang Mempengaruhi Status Gizi Pasien Selama Dirawat Di Bagian Penyakit Dalam RSUPN-CM. Media Dietetik AsDI, Edisi Khusus, 2002: 113 - 115.

3. Kusumayanti, Hamam Hadi, Susetyowati. Faktor-faktor Yang Mempengaruhi Kejadian Malnutrisi Pasien Dewasa Di Ruang Rawat Inap Rumah Sakit. Jurnal Gizi Klinik Indonesia vol. 1 ( 1 ): 9 - 17. 2004.

4. Defriani Dwiyanti, Hamam Hadi, Susetyowati. Pengaruh Asupan Makanan Terhadap Kejadian Malnutrisi Di Rumah Sakit. Jurnal Gizi Klinik Indonesia 2004: Vol. 1 (1): 1-7.

5. Syamsiatun, Hamam Hadi, Madarina Julia. Hubungan Antara Status Gizi Awal dengan Status Pulang dan Lama Rawat Inap Pasien Dewasa di Rumah Sakit. Jurnal Gizi Klinik Indonesia 2004 vol. $1(1): 28-33$.

6. Sastroasmoro S dan Ismael S. Dasar Dasar Metodologi Penelitian Klinis. Binarupa Aksara, 2004.

7. Departemen kesehatan RI. Pedoman Praktis Terapi Gizi Medis. Jakarta: Direktorat Gizi Masyarakat, 2003.

8. Departemen Kesehatan Rl. Pedoman Pelayanan Gizi Rumah Sakit. Jakarta: Direktorat Gizi Masyarakat, 2003.

9. Almatsier S. Penuntun Diet. Jakarta: Gramedia Pustaka Utama, 2004.

10. Almatsier S. Prinsip Dasar IImu Gizi. Jakarta: Gramedia Pustaka Utama, 2001.

11. Team Nutrisi Instalasi Gizi RS Sanglah Denpasar. Peraturan Pemberian 
Makanan Rumah Sakit. Denpasar: Team Nutrisi Instalasi Gizi, 2005

12. Perhimpunan Dokter Spesialis Gizi Klinik Indonesia. Pedoman Tata Laksana Gizi Klinik. Jakarta: PDGI, 2008

13. Supariasa IDN, Bakri B, Fajar I. Penilaian Status Gizi. Jakarta: Penerbit Buku Kedokteran, EGC, 2002.

14. Insel P, Turner RE, Ross D. Nutrition guide line and assessment. In: Nutrition. Update 2002. Boston: Jones and Barlett -American Dietetic Association, 2002.
15. Williams SR, Schlenker ED. Essentials of Nutrition \& Diet Therapy. 8th ed. Mosby, 2003.

16. Dinarto M. Tim Nutrisi. Gizi Medik Indonesia. 2002, 2002 1(1): 7-8. 